\title{
Predictable Stock Returns in the United States and Japan: A Study of Long-Term Capital Market Integration
}

\section{Citation}

Campbell, John Y., and Yasushi Hamao. 1992. Predictable stock returns in the United States and Japan: A study of long-term capital market integration. Journal of Finance 47, no. 1: 43-69.

\section{Published Version}

http://dx.doi.org/10.2307/2329090

\section{Permanent link}

http://nrs.harvard.edu/urn-3:HUL.InstRepos:3207694

\section{Terms of Use}

This article was downloaded from Harvard University's DASH repository, and is made available under the terms and conditions applicable to Other Posted Material, as set forth at http:// nrs.harvard.edu/urn-3:HUL.InstRepos:dash.current.terms-of-use\#LAA

\section{Share Your Story}

The Harvard community has made this article openly available. Please share how this access benefits you. Submit a story.

Accessibility 
NBER WORKING PAPER SERIES

PREDICTABLE STOCK RETURNS IN THE UNITED STATES AND JAPAN:

A STUDY OF LONG-TERM CAPITAL MARKET INTEGRATION

John Y. Campbe11

Yasushi Hamao

Working Paper No. 3191

NATIONAL BUREAU OF ECONOMIC RESEARCH

1050 Massachusetts Avenue

Cambridge, MA 02138

December 1989

This research has been supported by the National Science Foundation and the John M. Olin Fellowship at the NBER (Campbell), and the Dean witter Foundation (Hamao). We are grateful to the Financial Markets Group at the London School of Economics for its hospitality, to Daniel Hardy for able research assistance, to Daiwa Securities for providing some of he data, and to Rene Stulz and an anonymous referee for helpful comments on an earlier draft of the paper. This paper is part of NBER's research program in Financial Markets and Monetary Economics. Any opinions expressed are those of the authors not those of the National Bureau of Economic Research. 
NBER Working Paper \#3191

December 1989

PREDICTABLE STOCK RETURNS IN THE UNITED STATES AND JAPAN:

A STUDY OF LONG-TERM CAPITAL MARKET INTEGRATION

\section{ABSTRACT}

This paper studies the predictability of monthly excess returns on equity portfolios over the domestic short-term interest rate in the U.S. and Japan during the period 1971:1-1989:3. The paper finds that similar variables. including the dividend-price ratio and interest rate variables, help to forecast excess returns in each country. In addition, in the $1980^{\circ} \mathrm{s}$ U.S. variables help to forecast excess Japanese stock returns. There is evidence of common movement in expected excess returns across the two countries, which is suggestive of integration of long-term capital markets.

John Y. Campbe11

Woodrow Wilson School

Robertson Hall

Princeton University

Princeton, NJ 08544
Yasushi Hamao

Graduate School of International

Relations and Pacific Studies

Q-062, UC San Diego

La Jolla, CA 92093 


\section{Introduction}

There is by now a large literature documenting the fact that in the United States, excess stock returns move through time in a predictable fashion. For example, excess returns on broad equity portfolios over Treasury bills are forecast by the dividend-price ratio on stock, by the level of interest rates, by the long-term yield spread, and by the month of the year (the so-called "January effect"). 1

Much less research has been done on stock markets in the rest of the world. In the case of Japan there has been some work which documents the existence of a January effect, and some work on stock returns in relation to inflation, but to our knowledge there is no published study of the overall predictability of excess stock returns in Japan. 2

In this paper we study U.S. and Japanese stock market data simultaneously. We ask whether similar domestic variables forecast excess returns in the two countries, and then whether international variables improve the forecasts obtainable from domestic variables. We study the extent to which predictable movements in excess returns in Japan are correlated with those in the U.S. We estimate and test a highly restricted model in which expected excess returns in Japan and the

1 See Campbell (1987), Campbell and Shiller (1988), Fama and French (1988), Fams and Schwert (1977), Keim and Stambaugh (1986), among others.

2 One unpubliched paper which does present forecasts of Japanese stock returns is Sentana and Wadhwani (1989). See Gultekin and Gultekin (1983), Jaffe and Westerfield (1985), and Kato and Schallheim (1984) for the January effect in Japan. See Gultekin (1983) and Solnik (1983) for international evidence on inflation (measured directly or using shortterm interest rates) in relation to stock returns. Jaffe and Westerfield (1985) also look at day-of-the-week effects in Japan, as do Condoyanni, 0 'Hanlon and Ward (1988). Finally, Cumby (1987) tries to explain the predictability of stock returns in several countries using a consumption capital asset pricing model. 
U.S. are driven by a common unobserved variable, so that they are perfectly correlated. The model generates estimates of the component of expected excess returns which is common to both countries.

Our work has value as simple data description. But we are also interested in the extent to which U.S. and Japanese stock markets (and international long-term capital markets more generally) can be described as "integrated". If capital markets are integrated, then assets which are traded in different markets, but which have identical risk characteristics, will have an identical expected return. The difficulty in testing this is of course that one needs a particular asset pricing model in order to measure risk characteristics. A finding of imperfect integration can always be attributed to misspecification of one's model of risk.

Most comparative work on international stock markets has used crosssectional information on the unconditional mean returns of securities traded in different markets. A static asset pricing model (such as the CAPM or the APT with constant parameters) is estimated and used to test the null hypothesis that market risk prices are the same across countries, against the alternative that they differ. ${ }^{3}$

Our strategy is rather different. Instead of looking at the crosssectional pattern of mean returns on stock portfolios, we try to exploit the time-variation in expected stock returns in the U.S. and Japan. We will argue that common movement in expected excess returns in the two

3 See Cho, Eun and Senbet (1986), Gultekin, Gultekin and Penati (1989), Jorion and Schwartz (1986), and Stehle (1977). There is also some work on dynamic international asset pricing models, for example Cumby (1988) and Korajczyk (1985). 
countries is indirect evidence of integration. In particular, we would find perfectly correlated expected excess returns if capital markets are integrated and assets have constant betas on a single source of risk whose market price moves through time. ${ }^{4}$

of course, our approach is subject to the general difficulty with all tests of integration. For example, if Japanese and U.S. firms are exposed to different sources of risk, and if the prices of these risks move independently, then expected excess returns will move independently even if prices are set in a single world capital market.

Nevertheless we belleve that a finding of common movement is suggestive of integration. Common movement in expected returns means that some force is affecting the equilibrium return in the U.S. and Japanese stock markets in the same way. We are agnostic about what this force might be. The possibilities include changes in volatility or some broader measure of "business cycle risk" (Fama and French 1989), changes in the risk aversion of a representative agent as aggregate wealth rises and falls (Marcus 1989), and exogenous shifts in the demand for stock of "noise traders" which must be accommodated by utility-maximizing traders (Campbell and Kyle 1988). But if market-clearing takes place in the U.S. and Japanese stock markets independently, then equilibrium returns would move together only by coincidence.

4 For direct evidence that a single "world factor" affected ex post stock market returns in many countries at the time of the crash of 1987 , and that stock markets' responses to the crash were consistent with their historical betas on this factor, see Roll (1988).

5 Our argument can be seen as analogous to that of Feldstein and Horioka (1980). They argue that if international capital markets were perfectly integrated, then there would be no reason to expect savings and investment in a particular country to be correlated with one another. 
Our approach also differs from much of the existing literature in that we measure the excess returns on long-term assets in each country relative to a short-term interest rate denominated in the same currency. Thus exchange rate movements do not directly affect the excess returns studied in this paper. We could of course extend our approach to include the excess return on a short-term Japanese investment over a short-term U.S. Investment; this excess return could be used to convert our owncurrency excess returns into common-currency excess returns. However this type of excess return, across short-term investments in different currencies, has already been extensively studied in the literature. ${ }^{6}$

The organization of our paper is as follows. In section 2 we describe the asset pricing framework which motivates our empirical work. In section 3 we describe our data set. In section 4 we present preliminary regressions which document the existence of predictable excess stock returns. In section 5 we try to use the results from section 4 to characterize the extent to which U.S. and Japanese stock markets are integrated. We estimate a single-latent-variable model which restricts expected excess stock returns in the U.S. and Japan to move together. Section 6 extends the analysis to include returns on size-ranked portfolios of stocks, and section 7 concludes.

Evidence that these variables are correlated is suggestive that international capital markets are imperfectly integrated. Similarly, we argue that if international capital markets were entirely segmented, then there would be no reason to expect equilibrium returns in different countries to be correlated with one another. Evidence that expected returns are correlated is suggestive that international capital markets are integrated at least to some degree.

6 For a survey, see Obstfeld (1986). 


\section{The Asset Pricing Framework}

The most general asset pricing model we consider is a $\mathrm{K}$-factor model of the following form:

(1) $\overline{\mathbf{r}}_{i, t+1}-E_{t}\left[\bar{r}_{i, t+1}\right]+\sum_{k=1}^{K} \beta_{i k} E_{k, t+1}+\tilde{\epsilon}_{i, t+1}$.

Here $\bar{r}_{i, t+1}$ is the excess return on asset $i$ held from time to time $t+1$, the difference between the random real return on asset $i$ and the riskfree real rate of interest. The excess return on asset $i$ equals the expected excess return, plus the sum of $k$ factor realizations $f_{k, t+1}$ times their betas or factor loadings $\beta_{i k}$, plus an idiosyncratic error $\dot{\epsilon}_{i, t+1}$. The asset pricing model is dynamic in the sense that the expected excess. return can vary through time, but static in that the beta coefficients. are assumed to be constant through time.

The expected excess return is restricted by the model as follows:

(2) $E_{t}\left[\tilde{r}_{i, t+1}\right]=\sum_{k=1}^{K} \beta_{i k} \lambda_{k t}$.

where $\lambda_{k t}$ is the "market price of risk" for the k'th factor at time $t$. This type of restriction can be generated by any of a number of intertemporal asset pricing models.

Now suppose that the information set at time $t$ consists of a vector of $N$ forecasting variables $x_{n t}, n=1 \ldots N$ (where $x_{1 t}$ is a constant), and that conditional expectations are linear in these variables. Then the $k^{\prime}$ th risk price can be written 
(3) $\lambda_{k t}=\sum_{n=1}^{N} \theta_{k n} x_{n t}$,

and equation (2) becomes

(4) $E_{t}\left[\tilde{r}_{i, t+1}\right]-\sum_{k=1}^{K} \beta_{i k} \sum_{n=1}^{N} \theta_{k n} X_{n t}-\sum_{n=1}^{N} \alpha_{i n} x_{n t}$.

Equation (4) says that the IN coefficients $\alpha_{\text {in }}$ obtained by regressing I excess returns on $N$ forecasting variables can be written in terms of IK beta coefficients and $\mathrm{KN}$ coefficients which define market prices of risk.

There are two main ways in which this system can be used in empirical work. Either one can assume that certain factors are observable; or one can assume that factors are unobservable, but the number of factors is small relative to the number of assets and forecasting variables.

\section{Observable factors}

Suppose that we observe a portfolio whose return has a beta of one on the first factor, and zero on the other factors. Suppose further that the return on this portfolio has zero idiosyncratic risk. Call the return on this portfolio $\tilde{\mathrm{r}}_{1, t+1}$. Then we have

$$
\begin{aligned}
& \text { (5) } \overline{\mathbf{r}}_{i, t+1}-\beta_{i 1} \tilde{\mathrm{r}}_{1, t+1}+\sum_{\mathbf{k}=2}^{\mathrm{K}} \beta_{i k} \sum_{n=1}^{\mathrm{N}} \theta_{k n} \mathrm{X}_{n t}+\sum_{\mathbf{k}=2}^{\mathrm{K}} \beta_{i k} \mathrm{~F}_{k, t+1}+\bar{\epsilon}_{i, t+1} \\
& -\beta_{11} \tilde{r}_{1, t+1}+\sum_{n=1}^{N} a_{i n}^{*} x_{n t}+\dot{u}_{i, t+1} .
\end{aligned}
$$


In a regression of excess return $i$ on excess return 1 and the information variables $X_{n t}$, the inclusion of excess return 1 "soaks up". the time variation in the risk price for factor 1 . The coefficients on $x_{n t}, \alpha_{1 n}^{*}$ now reflect only the time variation in the risk prices for factors 2 through $k$. If these risk prices are zero, then all coefficients $\alpha_{\text {in }}^{*}$ will be zero; if these risk prices are constant, then the intercept $a_{i 1}^{\star}$ will be nonzero but the other coefficients $\alpha_{\text {in }}^{*}$ for $n-2 \ldots . N$ will be zero.

This approach can be applied in the international context as follows. Suppose we think that the Japanese stock market obeys a multi-factor model, where the first factor is an international factor and the other factors are domestic Japanese factors. Suppose that the International factor is well proxied by the U.S. stock market return. Then we can regress the Japanese market return on the U.S. market return and a set of forecasting variables. The variance of $\Sigma \alpha_{i n}^{*} X_{n t}$, relative to the variance of $\Sigma a_{i n} X_{n t}$ (the fitted value when the Japanese market is regressed only on $\mathrm{x}_{n t}$ ), is a measure of the variation in risk prices of domestic factors relative to the variation in the risk prices of all factors. In the extreme case where only the international factor is priced, the coefficients $\alpha_{i n}^{*}$ will all be zero. In the case where only the risk price for the international factor varies through time, the coefficients $\alpha_{\text {in }}^{*}$ will be zero apart from the intercept.

\section{Unobservable factors}

One objection to the above procedure is that it assumes that the U.S. stock market is an adequate proxy for the international factor in the asset pricing model. This gives the U.S. market a special role which may not be appropriate. 
An alternative approach is to assume that there is a single priced International factcr which is unobservable, and no priced domestic factors in either the U.S. or Japan. If we work with two stock returns, one from each country, and $N$ forecasting variables, then equation (4) imposes that $\alpha_{\text {in }}=\beta_{1}{ }^{\theta}$, where the $k$ subscript has been dropped since there is only one factor. The underlying parameters $\beta_{1}$ and $\theta_{n}$ are only Identified up to a normalization; if we normalize $\beta_{1}-1$, the restricted system can be written as

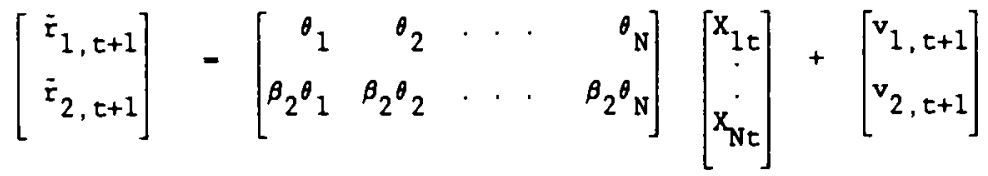

The first row of the coefficient matrix in (6) identifies the $\theta_{n}$ coefficients, the first column identifies the coefficient $\beta_{2}$, and the remaining $\mathrm{N}-1$ coefficients are restricted. These restrictions enforce a perfect correlation between the expected excess return in the U.S. market, and the expected excess return in the Japanese market. The restricted specification is sometimes called a single-latent-variable model. It can be estimated and tested using Hansen's (1982) Generalized Method of Moments, which allows for conditional heteroskedasticity in the variance-covariance matrix of returns.

The model (6) can be generalized to allow for unobserved domestic factors whose risk prices are constant or depend only on a subset of the $x_{n t}$. When such factors are present, the restrictions in (6) apply only

7 For more details on this model, see Hansen and Hodrick (1983), Gibbons and Ferson (1985), Campbel1 (1987), and Campbell and Clarida (1987). 
to those elements of the $x_{n t}$ which do not affect the risk prices of the domestic factors. Unfortunately, we cannot allow for arbitrary domestic factors because the model then becomes unidentified.

Even if the overidentifying restrictions of equation (6) are rejected, the estimated coefficients may still be of interest. The fitted values from (6) are the best possible forecasts of stock returns in the two countries subject to the restriction that the forecasts be perfectly correlated with one another; thus they can be interpreted as estimates of a common international component in expected stock returns. Below we will compare these estimates with unrestricted regression forecasts of stock returns in the two countries.

\section{How we measure returns}

Our discussion so far has proceeded under the assumption that we are measuring each asset return in real terms, relative to a common riskfree real return. In our application, we might pick the return on 1 -month U.S. Treasury bills deflated by the U.S. consumer price index as the riskfree real return, and measure all other returns relative to this.

This way of measuring excess returns can be simplified if we are willing to approximate the real return on an asset by the nominal return less the inflation rate of the appropriate price index. (The approximation holds exactly for continuously compounded returns.) Then the inflation rate cancels out of the expression for the excess return and we can avoid the need to measure the price index. We use this approach below.

We can also work with linear combinations of excess returns. For example, if we use the same kind of approximation for exchange rates as 
for inflation rates, then the excess yen return on the Japanese stock market relative to the Japanese short-term interest rate is approximately equal to the excess dollar return on the Japanese stock market relative to the dollar return on a short-term Japanese investment. ${ }^{8}$ This in turn is equal to the excess dollar return on the Japanese stock market relative to the U.S. short-term interest rate, less the excess dollar return on a short-term Japanese investment relative to the U.S. shortterm interest rate. If both the component excess returns obey the restrictions of equation (5) or equation (6), then the difference between them will also obey these restrictions. 9 Thus we can test our models using excess stock returns in each country measured relative to that country's own short-term interest rate. We use this procedure below. 10

\section{Omitted information variables}

In our empirical work we use forecasting variables $x_{n t}$ which are known to the market at time $t$. Generally, we do not wish to assume that we have included all the relevant variables. Fortunately, the methods

8 For an alternative analysis, which does not rely on the approximation above, see Stulz (1981). Stulz presents a continuous-time model in which the covariance between stock returns and exchange rate movements (which creates approximation error in our approach) appears explicitly. In Stulz's model the covariance is assumed to be constant, which means that it will not affect empirical work based on time variation in expected returns.

9 A special case would be uncovered interest parity. In this case the expected excess dollar return on a short-term Japanese investment relative to the U.S. short-term interest rate is zero, so it trivially obeys the restrictions of equation (6). But uncovered interest parity is not required for our procedure to be valid. This is fortunate, since there is considerable evidence against uncovered yen/dollar interest parity.

10 We obtained very similar results when we ran regressions for excess returns measured in dollars relative to the U.S. short-term interest rate. 
described above are robust to omitted information. By taking conditional expectations of equations (5) and (6), it is straightforward to show that the various restrictions hold in the same form when a subset of the relevant information is used. Thus if the coefficients $\alpha^{*}$ in equation (5) are zero for the true information vector used by the market, they w11l also be zero if a subset of this vector is included in (5). Similarly, if the market's forecasts of excess returns in the two countries are perfectly correlated, then forecasts using a subset of the market's information must also be perfectly correlated. 


\section{Data and Sample Period}

The comparative approach of this paper requires that the data be comparable across the two countries to the greatest extent possible. The last month for which we are able to obtain complete data in both countries is March 1989.

\section{U.S. data}

For the U.S., we use standard publicly available data. Stock prices. and dividends are taken from the Center for Research on Security Prices (CRSP) monthly stock tape. We study a value-weighted index of New York Stock Exchange stocks, and also a set of equally-weighted portfolios, organized by firm size. ${ }^{11}$ We use a 1 -month Treasury bill yield as our short-term interest rate, and a long-term (approximately 20-year) government bond yield to compute the long-short yleld spread. These series are from Ibbotson Associates (1989).

\section{Japanese data}

The most commonly used and readily available Japanese stock price indexes are the Nikkei 225 and the Tokyo Stock Exchange Price Index (TOPIX). These indexes, however, are not comparable with the CRSP valueweighted New York Stock Exchange index. The Nikkei index is a priceweighted index of only 225 stocks out of more than 1500 stocks 1 isted currently on the Tokyo Stock Exchange, representing about 508 of total capitalization. The TOPIX is a value-weighted index constructed from all

11 The size portfolios are rebalanced monthly according to capitalization at the end of the previous month. For the last 15 months of the sample, 1988:1-1989:3, we were obliged to use the dividend yleld on the S\&P 500 index in place of the dividend yield on the CRSP valueweighted portfolio. In earlier years these two series move very closely together, so this substitution is unlikely to have any noticeable effect on our empirical results. 
the stocks traded on the first section of the Tokyo Stock Exchange with 97 of the total (first and second section) capitalization, but neither TOPIX nor Nikkei properly account for dividend payments.

We therefore constructed our value-weighted index from individual stock returns including and excluding dividends. ${ }^{12}$ The universe of stock used is the Tokyo Stock Exchange, first and second sections; foreign firms listed on the TSE are excluded from the sample. ${ }^{13}$ our database is an extension of the one presented in detail in Hamao $(1988,1989)$ and Hamao and Ibbotson (1989), and it starts in January 1970. Since we need one year's lag in order to construct a 1 -year moving average dividendprice ratio, our sample period starts in January 1971.

Japanese bond markets did not develop until the 1970's, and data are therefore not available before 1970 . There is no equivalent of Treasury bills in Japan; thus the short-term interest rate used here is a combined series of the call money rate $(1971: 1-1977: 11)$ and the Gensaki rate (1977:12-1988:12). The Gensaki rate, an interest rate applied to bond repurchase agreements, is less subject to regulation than the call money rate, but it became available only after 1977 . The call money rate is the "unconditional" rate, which is applied to transactions maturing in less than one month, and the Gensaki rate we use has one month maturity. The long-term Japanese government yield we use is for bonds with 9 to 10 years to maturity, which is the longest consistently available maturity.

12 Our Japanese individual stock returns data were compiled from the raw data on prices kept by Daiwa Securities and adjusted for dividend payments, stock splits, etc. This database is comparable to the CRSP files.

13 Our U.S. sample does include a few Japanese firms in the form of American Depositary Receipts, but overall there is minimal cross-listing. 


\section{Sample period}

Limitations on the availability of Japanese data, discussed above, confine us to the sample period 1971:1-1989:3. Within this period, financlal markets in both countries have undergone some institutional changes. The system of financial regulation in the U.S. has changed gradually through the period we study, but Japanese capital markets have experlenced a more radical deregulation. ${ }^{14}$ Before 1970 , there was virtually no free short-term interest rate. Although the Gensaki market grew substantially in the $1970^{\prime} s$, it was not until 1978 that the authorities completely lifted restrictions in the short-term market. After the first issue of government bonds in 1966, financial institutions, which were the major bondholders, were not allowed to sell government bonds in a secondary market until 1977.

More recently a major deregulation occurred with the revision of the Foreign Exchange Law in December 1980. The old Foreign Exchange Law prohibited all transactions with foreign countries in principle, whereas under the new law controls over many types of capital flow have been removed. For example, it is now possible for a forelgner to invest in up to 10 of of the equity of a Japanese company without the permission of the Ministry of Finance. With this deregulation, along with the development of the secondary bond market in the $1980^{\circ} \mathrm{s}$, it is natural to divide the whole period 1971:1-1989:3 (219 observations) 1nto two subsamples, 1971:1-1980:12 (120 observations) and 1981:1-1989:3 (99 observations).

14 See Pigott (1983), Japanese Ministry of Finance (1987) and Suzuki (1987) for a description of Japanese financial deregulation. 
4. Forecasting Excess Returns on Value-Weighted Stock Indexes in the United States and Japan

Table 1 reports basic statistics which summarize the behavior of some of the most important varlables we study. For each variable we report the mean and standard deviation of the U.S. and Japanese series, and the correlation between the U.S. and Japanese series, over the full sample and both subsamples.

At the top of the table we give statistics for the excess returns on the U.S. and Japanese value-weighted Indexes over each country's domestic short-term interest rate. Monthly returns are measured at an annual rate. Japanese stocks have a higher mean return than U.S. stocks in both the 1970's and the 1980's, but the gap widens in the 1980's with the sustained rise in the Japanese market. The correlation between U.S. and Japanese stock returns is fairly stable in the range 0.3 to about 0.4 .

For comparison, we also summarize the behavior of the excess dollar return on Japanese stocks over the U.S. short-term interest rate. The mean of this series is somewhat higher, reflecting yen appreciation over the period; the standard deviation is higher and the correlation with excess returns on U.S. stocks is lower. The two Japanese excess return series have a correlation of about 0.8 .

Next we look at the behavior of dividend-price ratios on the two stock indexes (where the dividend is the average over the previous year, and the price is the current price). Dividend-price ratios have been found to predict excess returns in the U.S., and they will be important explanatory variables in our regression analysis. We find that the Japanese dividend-price ratio has a lower mean than the U.S. dividend- 
price ratio (in fact, it has been lower than the U.S. In every month since the mid-1970's). The Japanese dividend-price ratio has been falling over time, again reflecting the rise in Japanese stock prices during the $1980^{\prime} s .^{15}$ The U.S. and Japanese series are negatively correlated in the $1970^{\prime} \mathrm{s}$, but highly positfvely correlated in the $1980^{\prime} \mathrm{s}$. Figure 1 plots the two countries' dividend-price ratios, and these characteristics of the data can be clearly seen.

We repeat the exercise for levels of and changes in the U.S. bill rate and the Japanese short rate, again measured at an annual rate. These interest rates will also be used as forecasting variables for excess returns. U.S. interest rates tend to rise slightly over the full sample. period, while Japanese rates fall; however the medium-run movements of the two interest rates are positively correlated. For this reason the rates have higher correlations over the subsamples than over the whole sample period. In the short run, month-by-month changes in the two interest rates are only very weakly correlated and are more variable in the U.S. than in Japan.

Finally, we report summary statistics for the long-short yield spread in the two countries. The U.S. and Japanese yield spreads are weakly positively correlated, with a higher mean in the U.S. Figures 2 and 3 show the history of short-and long-term interest rates in the U.S. and Japan, respectively.

15 For a more detailed analysis of Japanese dividend yields and the level of the Japanese market, see French and Poterba (1989). 


\section{Forecasting excess stock returns with domestic variables}

In Table 2 we regress excess returns in the U.S. and Japan on a variety of forecasting variables. U.S. results appear on the left hand side of the table, and Japanese results on the right hand side. For each country we use forecasting variables which are specific to that country. We report coefficients, with heteroskedasticity-consistent standard errors in parentheses, for the whole sample and each subsample. ${ }^{16}$ For each regression, we also report the adjusted $R^{2}$ statistic, the joint significance of the coefficients (excluding a constant term and January dummy), and the significance level for a test of stability of the coefficients across subsamples.

We begin Table 2 by testing the significance of the January effect. In the U.S., a regression of the excess stock return on a January dumm yields positive but insignificant coefficients, with a decline from the $1970^{\prime}$ 's to the $1980^{\prime} \mathrm{s}$. In Japan, on the other hand, the January dummy is signiflcant at the 2 or 38 level in the full sample and each subsample. We include the January dummy in all our subsequent regressions but do not report its estimated value.

Next we regress the excess stock return on the domestic dividend-price ratio. We find weak evidence that this variable has forecasting power. In the U.S., the estimated coefficient is positive in the full sample and each subsample; it is significant at almost the 5 level in the $1970^{\prime} \mathrm{s}$, but insignificant in the $1980^{\prime} \mathrm{s}$. In Japan, the coefficient is positive and highly significant in the 1970's, but negative and insignificant in

16 The heteroskedasticity-consistent standard errors are generally quite similar to the ordinary standard errors in these regressions. 
the 1980's. This of course reflects the fact that the Japanese market continued to perform well in the 1980's even when Japanese dividend yields fell below their historical range.

The next regression forecasts the stock return using the short-term interest rate. This variable too has some explanatory power. In each country and sample period the estimated coefficient is negative, but its statistical significance varies greatly. The interest rate effect is strongest in the U.S. in the 1980's, and in Japan in the 1970's.

When we combine the dividend-price ratio and the short-term interest rate, we obtain a forecasting model which is very successful in the U.S. data. The dividend-price ratio has a consistently positive sign, while the short-term interest rate is consistently negative. The adjusted $R^{2}$ is about 0.1 , and the variables are jointly significant at the 18 level, over the full sample and each subsample. There is no evidence that the estimated coefficients change from the 1970's to the 1980's. In Japan, the estimates are very similar to the U.S. In the $1970^{\prime} s$, with an even higher $\mathrm{R}^{2}$ of almost 138 . However the forecasting model breaks down completely in the 1980 's.

One possible objection to the results presented so far is that the short-term interest rate may be nonstationary, as suggested by Campbell and Shiller (1987) among others. If the short rate is nonstationary, then test statistics from a regression of stock returns on the short rate will not have the standard asymptotic distribution. Even if the short rate is stationary but highly serially correlated, there can be finitesample difficulties as pointed out by Mankiw and Shapiro (1986) and 
Stambaugh $(1986) \cdot 17$

Accordingly, in the rest of Table 2 we experiment with other variables which can be combined with the short rate to produce a stationary time series. We first replace the level of the 1 -month interest rate with the change in the interest rate. This variable has forecasting power in the $1970^{\prime} \mathrm{s}$, but not in the $1980^{\prime} \mathrm{s}$.

Next we take the difference between the long-term government bond yield and the level of the short rate. As Campbell and Shiller (1987) point out, this long-short yield spread will be stationary if term premia and changes in short rates are stationary. The yield spread is a successful forecasting variable (with a positive coefficient) in every sample period in the U.S., and in the 1970's in Japan.

Finally, when we estimate a system including the dividend-price ratio, the lagged change in the short rate, and the long-term yield spread, we obtain strong joint significance levels in the $1970^{\prime} \mathrm{s}$ but much weaker ones in the 1980's. The deterioration in forecast power is less serious in the U.S. (where the yield spread remains individually significant) than in Japan.

In summary, Table 2 provides considerable evidence that U.S. and Japanese stock returns can be forecast using similar types of domestic variables. The major qualification to this statement is that the predictability of Japanese returns seems to disappear in 1981-89.

17 A similar objection could be made to the use of the dividend-price ratio in our regressions. The Japanese dividend-price ratio, in particular, is characterized by low-frequency movement in the 1980 . s. 


\section{Forecasting excess stock returns with international variables}

In Table 3 we push the investigation one stage further. We regress U.S. and Japanese excess returns on a common international set of forecasting variables. This enables us to see whether foreign-country variables have any ability to predict excess returns when they are added to domestic variables. We first use a relatively small set of international forecasting variables (a.January dummy, and U.S. and Japanese dividend-price ratios and short rates), and then a larger set which excludes the level of the short rate (a January dummy, and U.S. and Japanese dividend-price ratios, changes in short rates, and long-short yield spreads). We will call the first specification the "short rate level" specification, and the second the "yield spread" specification.

In Table 3 we find no evidence that Japanese variables help to forecast U.S. stock returns. None of the Japanese variables are individually or jointly significant. We also find no evidence that U.S. variables help to forecast Japanese stock returns in the 1970's.

In the 1980's, however, when Japanese variables fail to predict Japanese returns, we find that U.S. variables do come in. The adjusted $\mathrm{R}^{2}$ statistics rise from 0.01 to 0.11 when the $U . S$. variables are added to the short rate level specification, and from 0.03 to 0.09 when the U.S. variables are added to the yield spread specification. ${ }^{18}$ Both countries' data are needed for successful forecasting; a regression of Japanese stock returns on U.S. variables alone has an adjusted $R^{2}$ of less than

18 This finding seems to be consistent with the results of Hamao, Masulis, and $\mathrm{Ng}$ (1989) for high-frequency data. They find that the Japanese stock market is more sensitive to foreign shocks than are the American or British stock markets. 
0.02 in either specification. As one would expect, there is strong evidence of instability between the 1970's and the 1980's in the coefficients of the international forecasting equations for Japanese stock returns.

Both of the international specifications for Japanese stock returns include the U.S. and Japanese dividend-price ratios. These variables enter with extremely large coefficients of opposite sign: in the short rate level specification, for example, the forecast of the Japanese stock return is 80 times the Japanese dividend-price ratio minus 41 times the U.S. dividend-price ratio. This result can be better understood if one recalls that the U.S. and Japanese dividend-price ratios have a very high correlation of 0.89 in the 1980's (see Table 1). The U.S. dividend-price ratio has more than double the standard deviation of the Japanese dividend-price ratio. Thus the regression seems to be forecasting Japanese stock returns using the difference between the two countries' dividend-price ratios, weighted inversely by their standard deviations. ${ }^{19}$ This variable is positively correlated with each country's dividend-price ratio, even though it is formed as a difference, because of the strong positive correlation of the two components. It peaks in 1982; the corresponding peak in the fitted value of the regression is shown in Figure $5 b$ below.

19

We also tried replacing the levels of the two dividend-price ratios with their logs. We obtained a regression equation with a similar forecasting power, and coefficients on the U.S. and Japanese log dividend-price ratios which were opposite in sign. The coefficient on the Japanese log dividend-price ratio was somewhat larger in magnitude. These results are consistent with those in Table 3 . 


\section{Some Evidence on Capital Market Integration}

We have found evidence that similar types of variables help to predict stock returns in the U.S. and Japan. In the 1970's, the parallel behavior of the two markets is particularly clear. In the 1980's, there is little or no predictability of Japanese returns using Japanese variables alone. But in this period there is an interesting crosscountry effect: when U.S. variables are added to the forecasting equation, it becomes possible to predict Japanese stock returns with an $\mathrm{R}^{2}$ of about $10 \%$. The next question we consider is whether these facts are consistent with any of the simple models of an integrated world capital market that we presented in section 2 .

\section{An observable factor model}

In Table 4 we estimate a regression in the form of equation (5). We add the excess U.S. stock return to the regression of the excess Japanese return on forecasting variables. If the predictability of Japanese returns is due merely to the changing risk price of an international factor, which is adequately proxied by the U.S. market, then the inclusion of the U.S. stock return in the regression should destroy the significance of the forecasting variables.

In fact the presence of the U.S. stock return has very little effect on the other coefficients in the regression. The U.S. return gets a coefficient between 0.25 and 0.45 (this is the "beta" of the Japanese index on the U.S. Index), but the other variables remain just as significant as they were before. ${ }^{20}$

20 Given the instability of the Japanese regression coefficients, we present only subsample results. Full sample results are similar. 


\section{An unobservable factor model}

We next ask whether predictable excess stock returns in the U.S. and Japan move together through time. As discussed in section 2, if international capital markets are integrated and predictable excess returns are due to changes in the price of risk of a single world factor, then one would expect to find common movement in expected excess returns in the U.S, and Japan.

It is important to note that common movement of fitted values can occur even in the absence of the cross-country effect discussed above. It is possible that the U.S. and Japanese domestic forecasting variables are correlated in such a way that the domestic forecasts of excess returns are highly correlated. In fact Table 5 shows that the sample correlations of fitted values from the short rate specification in Table 3 are 0.44 in the $1970^{\prime} \mathrm{s}$ and 0.24 in the $1980^{\prime} \mathrm{s}$. These correlations are somewhat increased by the presence of the January effect; if one looks at deseasonalized fitted values, the correlations fall to 0.32 and 0.08 . Thus in the 1970 's, when there are no significant cross-country effects, the U.S. and Japanese fitted values are moderately correlated; in the $1980^{\prime} \mathrm{s}$, when international variables are essential for forecasting Japanese stock returns, the fitted values are much less correlated.

One problem with the discussion so far is that it does not take into account the sampling error in the coefficients of Table 3 . Without further analysis, we cannot be sure that the correlations of the fitted values are significantly different from zero or one. In fact, we shall now show that a model with perfectly correlated expected returns fits the data about as well in the 1980's as in the 1970's. 
In Table 5 we estimate a single-latent-variable model of the form (6). This model imposes the testable restriction that expected excess stock returns are perfectly correlated across countries. We work with demeaned stock returns at the left of the table, and with demeaned and deseasonalized returns (the residuals from a regression of returns on a constant and January dumm) at the right of the table. The forecasting variables are the same ones used in the short rate and yleld spread specifications of Table 3. Given the instability of the Japanese coefficients, we estimate the system separately for the 1970's and the $1980^{\prime} \mathrm{s}$.

The first excess return in the system is the U.S. excess stock return; therefore we normalize the $\beta$ for the U.S. to equal one. The free coefficients of the model are then the $\theta_{n}, n-1 \ldots N$, and the $\beta$ coefficient for the Japanese excess return. In Table 5 we report the Japanese $\beta$ with an asymptotic standard error in parentheses. (To save space, the $\theta_{n}$ coeffictents are not reported.) The system is estimated, and the overidentifying restrictions are tested, over the full sample period and each of the subsamples.

Table 5 shows that there is some evidence against a model with a single unobservable factor, but it is much weaker than the evidence for predictable stock returns in each country. In the short rate specification, the model (6) is rejected at the 88 level when the January dummy is restricted, and at the 48 level when the dumny is left unrestricted. Presumably this is due to the fact that the January dummy obeys the model restrictions; leaving it unrestricted saves on degrees of freedom without reducing the value of the test statistic. It is 
important to note that the significance levels at which the model is rejected do not change much from the 1970's to the $1980^{\circ} \mathrm{s}$, even though the unrestricted correlations of regression fitted values are lower in the 1980's.

Another way to evaluate the performance of the model with a single unobservable factor is to compare the variance of the restricted forecast with the variance of the unrestricted forecast from Table 3 . If the restricted variance is much smaller than the unrestricted variance, then the restrictions are causing a serious deterioration in forecast power. In Table 5 we report the ratio of the two variances for the U.S. and Japanese markets. In the short rate specification the ratio is above 0.8 for Japan and between 0.3 and 0.5 for the U.S., indicating that the restricted model is fitting Japanese returns at some cost to the quality of its U.S. forecasts. Once again there is little change in these numbers between the 1970's and the 1980's.

A visual impression of these results is given in Figures 4 and 5 . These figures plot the unrestricted versus the restricted fitted values from the short rate level specification over the 1970's (Figure 4) and the 1980's (Figure 5). Figures $4 a$ and $5 a$ show the fitted values for the U.S. market, while Figures $4 b$ and $5 b$ show the fitted values for the Japanese market. All fitted values were demeaned before plotting. It is apparent that in beth countries the 1970's were characterized by large low-frequency swings in expected returns, with a decline from 1971 to 1974, a rise from 1974 to 1978, and a second decline from 1978 to 1980. In the 1980's there is no such clear pattern, although the peak expected excess return occurred in 1982 or 1983 for each country. 


\section{Forecasting Excess Returns on Size-Ranked Stock Portfolios in the}

\section{United States and Japan}

It is well known that small stock returns in the U.S. display some anomalous behavior, particularly a strong January effect. As a final empirical exercise, we look at size-ranked portfolios of U.S. and Japanese stocks. We examine a portfolio of stocks formed by equally weighting the firms in the first quintile of market value (the smallest one fifth of the market), an equally-weighted portfolio of stocks in the third quintile, and an equally-weighted portfolio of stocks in the fifth quintile (the largest one fifth of the market). These portfolios are rebalanced every month.

Table 6 summarizes the results of regressing these portfolio returns on the international variables which were used in Table 3 . To save space we report only the adjusted $R^{2}$ statistics and significance levels, not the full set of coefficients.

The general pattern in Table 6 is that small stock returns are more predictable than large stock returns. This is partly due to the strong January effect in small stock returns, but the significance levels for the other forecasting variables also tend to be stronger in the small stock regressions. The exception to this pattern is that returns on large Japanese stocks in the $1980^{\prime}$ 's are more predictable than returns on small Japanese stocks.

In Table 7 we estimate single-latent-variable models for matched pairs of U.S. and Japanese size portfolios. The table reports the significance levels at wich the model restrictions are rejected. In the $1970^{\circ}$ s the latent variable specification is always rejected at the 10 o level, but 
not always at the 5 level. The rejections are stronger for small stocks. It is tempting to interpret this finding as reflecting the fact that the expected returns on large firms are primarily determined by the changing price of a common incernational source of risk, whereas small firms are exposed to domestic sources of risk. But the stronger rejections for small stocks could also result simply from the fact that small stock returns have greater predictable variation. In the $1980^{\circ} \mathrm{s}$, the test results for the single-latent-variable model are more erratic and dependent on the particular specification used. 


\section{Conclusion}

In this paper we have compared the predictable components of excess stock returns in the U.S, and Japan. Our main results are as follows:

1. In both countries it is generally possible to forecast excess stock returns over the domestic short-term interest rate using similar sets of domestic variables. The domestic dividend-price ratio and long-short yield spread have a generally positive effect on excess stock returns, while the short rate and the change in the short rate have a negative effect. These effects are fairly stable in the U.S. between the 1970's and the 1980's, but in Japan they are much weaker in the 1980's.

2. Japanese variables do not help to forecast U.S. excess stock returns, but U.S. variables do help to forecast Japanese excess stock returns in the $1980^{\prime} \mathrm{s}$. In particular, the level of the Japanese dividend-price ratio relative to the U.S. dividend-price ratio is a powerful forecasting variable.

3. Expected excess stock returns in the U.S. and Japan are positively correlated, particularly in the 1970's. There is some evidence against the hypothesis that expected excess stock returns in the two countries are perfectly correlated, but the evidence is not overwhelming. In both the 1970's and the 1980's, estimates of the common component of expected returns explain 30 or 408 of the variance of expected returns in the U.S., and 80 of the variance of expected returns in Japan.

4. The predictability of excess stock returns is generally stronger for small stocks. In the 1970's, small stocks also provide the strongest evidence against the hypothesis that expected excess stock returns are perfectly correlated across countries. 
These results are consistent with the view that expected stock returns are determined largely by the changing price of risk of a single common factor in a world capital market. In this sense our results suggest that U.S. and Japanese stock markets are substantially integrated. We find the degree of integration to be fairly constant from the 1970's to the $1980^{\prime}$ s. More generally, our results should help to guide research on the causes of changing expected stock returns in the United States. Whatever these causes are, they cannot be entirely local but must have the potential to move expected stock returns in other countries as well. 


\section{Bibliography}

Campbe11, John Y., "Stock Returns and the Term Structure", Journal of Financial Economics 18:373-399, June 1987 .

Campbell, John Y. and Richard H. Clarlda, "The Term Structure of Euromarket Interest Rates: An Empirical Investigation", Journal of Monetary Economics 19:25-44, January 1987.

Campbe11, John Y. and Albert S. Kyle, "Smart Money, Noise Trading, and Stock Price Behavior", National Bureau of Economic Research Technical Working Paper No. 71, October 1988.

Campbell, John Y. and Robert J. Shiller, "Cointegration and Tests of Present Value Models", Journal of Political Economy 95:1062-1088, October 1987.

Campbel1, John Y. and Robert J. Shiller, "Stock Prices, Earnings and Expected Dividends", Journal of Finance 43:661-676, July 1988 .

Cho, D. Chinhyung, Cheol S. Eun and Lemma W. Senbet, "International Arbitrage Pricing Theory: An Empirical Investigation", Journal of Finance 41:313-330, June 1986 .

Condoyanni, L., J. O'Hanlon and C.W.R. Ward, "Weekend Effects in Stock Market Returns: International Evidence", in Elroy Dimson ed. Stock Market Anomalies 52-63, Cambridge University Press 1988.

Cumby, Robert E., "Consumption Risk and International Asset Returns: Some Empirical Evidence", National Bureau of Economic Research Working Paper No. 2383, September 1987.

Cumby, Robert E., "Is It Risk? Explaining Deviations from Uncovered Interest Parity", Journal of Monetary Economics 22:279-299, September 1988 .

Fama, Eugene F. and Kenneth R. French, "Dividend Yields and Expected Stock Returns", Journal of Financial Economics 22:3-25, October 1988.

Fama, Eugene F. and Kenneth R. French, "Business Conditions and Expected Returns on Stocks and Bonds", forthcoming Journal of Financial Economics, 1989 .

Fama, Eugene F. and G. William Schwert, "Asset Returns and Inflation", Journal of Financial Economics 5:115-146, 1977.

Feldstein, Martin and Charles Horioka, "Domestic Saving and International Capital Flows", Economic Journal 90:314-329, 1980.

French, Kenneth R. and James M. Poterba, "Are Japanese Stock Prices Too High?", unpublished paper, August 1989. 
Gibbons, Michael R. and Wayne Ferson, "Testing Asset Pricing Models with Changing Expectations and an Unobservable Market Portfolio", Journal of Financial Economics 14:217-236, 1985.

Gultekin, N. Bulent, "Stock Market Returns and Inflation: Evidence from Other Countries", Journal of Finance 38:49-65. March 1983.

Gultekin, N. Bulent and Mustafa N. Gultekin, "Stock Market Seasonality: International Evidence", Journal of Financial Economics $12: 469-481,1983$.

Gultekin, N. Bulent, Mustafa N. Gultekin and Alessandro Penati, "Capital Controls and International Capital Market Segmentation: The Evidence from the Japanese and American Stock Markets", Journal of Finance 44:849-869, September 1989.

Hamao, Yasushi, "An Empirical Examination of the Arbitrage Pricing Theory: Using Japanese Data", Japan and the World Economy 1:45-61, 1988.

Hamao, Yasushi, "Japanese Stocks, Bonds, Bills, and Inflation", Journal of Portfolio Management 15:20-26, 1988.

Hamao, Yasushi, in collaboration with Roger Ibbotson, Stocks. Bonds, and Inflation - Japan. 1989 Yearbook, Chicago, IL: Ibbotson Associates, 1989.

Hamao, Yasushi, Ronald Masulis, and Victor Ng, "Correlations in Price Changes and Volatility Across International Stock Markets", forthcoming Review of Financial Studies, 1989.

Hansen, Lars Peter, "Large Sample Properties of Generalized Method of Moments Estimators", Econometrica 50:1029-1054, July 1982.

Hansen, Lars Peter and Robert J. Hodrick, "Risk Averse Speculation in the Forward Foreign Exchange Market: An Econometric Analys is of Linear Models", in Jacob A. Frenkel ed. Exchange Rates and International Macroeconomics, Chicago: University of Chicago Pŗess, 1983.

Ibbotson Associates, Stocks. Bonds. Bills, and Inflation - 1989 Yearbook. Chicago, IL: Ibbotson Associates, 1989 !)

Jaffe, Jeffrey and Randolph Westerfield, "Patterns in Japanese Common Stock Returns: Day of the Week and Turn of the Year Effects", Journal of Financial and Ouantitative Analysis 20:261-271, June 1985.

Japanese Ministry of Finance, Qkura-Sho Kokusal Kinyuu Kyoku Nenpo (Annual Report of the International Finance Division), Tokyo: Kinyuu Zaisei Jijo Kenkyuu Kai, 1987.

Jorion, Philippe and Eduardo Schwartz, "Integration vs. Segmentation in the Canadian Stock Market". Journal of Finance 41:603-613, July 1986. 
Kato, Kiyoshi and James S. Schallheim, "Seasonal and Size Anomalies in the Japanese Stock Market", Journal of Financial and Quantitative Analys is 20:243-259, June 1985 .

Keim, Donald B. and Robert F. Stambaugh, "Predicting Returns in the Stock and Bond Markets", Journal of Financial Economics 17:357-390, December 1986.

Korajczyk, Robert A., "The Pricing of Forward Contracts for Foreign Exchange", Journal of Political Economy $93: 346-368,1985$.

Mankiw, N. Gregory and Matthew D. Shapiro, "Do We Reject Too Often? Small Sample Properties of Tests of Rational Expectations Models", Economics Letters 20:139-145.

Marcus, Alan J., "An Equilibrium Theory of Excess Volatility and Mean Reversion in Stock Market Prices", National Bureau of Economic Research Working Paper No. 3106, September 1989.

Obstfeld, Maurice, "How Integrated are World Capital Markets: Some New Tests", NBER Working Paper No. 2075, November 1986.

Pigott, Charles, "Financial Reform in Japan", Economic Review, Federal Reserve Bank of San Francisco, 1:25-46, 1983.

Rol1, Richard, "The International Crash of October 1987", in Robert Kamphuis et al. eds. Black Monday and the Future of Financial Markets, Homewood, IL: Irwin, 1988.

Sentana, Enrique and Sushil Wadhwani, "Semi-Parametric Estimation and the Predictability of Stock Market Returns: Some Lessons from Japan", unpublished paper, London School of Economics, April 1989.

Solnik, Bruno, "The Relation between Stock Prices and Inflationary Expectations: The International Evidence", Journal of Finance 38:35-48, March 1983.

Stambaugh, Robert F., "Bias in Regressions with Lagged Stochastic Regressors", unpublished paper, Graduate School of Business, University of Chicago, 1986.

Stehle, Richard, "An Empirical Test of the Alternative Hypotheses of National and International Pricing of Risky Assets", Journal of Finance $32: 493-502$, May 1977 .

Stulz, Rene M., "A Model of International Asset Pricing", Journal of Financial Economics 9:383-406, 1981 .

Suzuki, Yoshio ed., The Japanese Financial System, Oxford: Clarendon Press, 1987 . 
TABLE 1

SUMMARY STATISTICS FOR U.S. AND JAPANESE DATA

\section{Excess Value-Weighted Stock Return}

U.S.

Japan (yen)

Sample

period

Mean $\begin{array}{r}\text { Standard } \\ \text { deviation }\end{array}$

Mean

Standard

US/Japan

deviation

correlation

$71-89$

$71-80$

0.049

0.570

0.115

0.520

0.358

0.035

0.572

0.082

0.513

0.156

0.529

0.308

0.570

0.415

\section{Japan (dollars)}

\begin{tabular}{|c|c|c|}
\hline Mean & $\begin{array}{l}\text { Standard } \\
\text { deviation }\end{array}$ & $\begin{array}{l}\text { US/Japan } \\
\text { correlation }\end{array}$ \\
\hline
\end{tabular}
0.163
0.674
0.284
0.817
0.144
0.637
0.270
0.827
0.185
0.719
0.299
0.808

\section{Value-Weighted Dividend-Price Ratio}

U.S.

Japan

Sample

period

$71-89$

$71-80$

$81-89$
Mean Standard

deviation

$0.041 \quad 0.009$

0.041

0.042

0.009

0.008

Mean

Standard

US/Japan deviation correlation

[CONTINUED] 
TABLE 1 (CONTINUED)

SUMMARY STATISTICS FOR U.S. AND JAPANESE DATA

\section{Short-term Interest Rate}

U.S.

Japan

Sample

period

$71-89$

$71-80$

$81-89$

Mean $\begin{array}{r}\text { Standard } \\ \text { deviation }\end{array}$

0.074

0.066

0.083
0.028
0.025
0.028

Mean

0.067

0.075

0.057
Standard deviation

0.024

0.028

0.013
US/Japan correlation

0.222

0.284

0.710

\section{Change in Short-term Interest Rate}

U.S.

Mean $\begin{array}{r}\text { Standard } \\ \text { deviation }\end{array}$

0.000

0.001

$-0.001$

$$
\begin{aligned}
& 0.011 \\
& 0.011
\end{aligned}
$$

0.011

Japan

Mean

0.019

0.014

0.025
U.S.

Long-Short Spread

$71-89$

$71-80$

$81-89$

Standard
deviation

0.017

0.016

0.016

$$
\text { Japan }
$$

Mean $\begin{array}{r}\text { Standard } \\ \text { deviation }\end{array}$

US/Japan correlation

0.198

0.169

$\begin{array}{lll}0.005 & 0.019 & 0.198 \\ 0.001 & 0.024 & 0.169 \\ 0.010 & 0.007 & 0.109\end{array}$

Notes: The sample periods for this table are 1971:1-1989:3, 1971:1-1980:12, and 1981:1-1989:3, with 219, 120, and 99 observations respectively. 
TABLE 2

FORECASTING EXCESS STOCK RETURNS

WITH DOMESTIC VARIABLES

U.S. STOCK RETURNS

JAPANESE STOCK RETURNS

\begin{tabular}{|c|c|c|c|c|c|c|}
\hline & 71.89 & $71 \cdot 80$ & $81-89$ & $71-89$ & $71-80$ & 81.89 \\
\hline $\begin{array}{l}\text { January } \\
\text { dummy }\end{array}$ & $\begin{array}{c}0.282 \\
(0.163)\end{array}$ & $\begin{array}{c}0.312 \\
(0.239)\end{array}$ & $\begin{array}{c}0.247 \\
(0.218)\end{array}$ & $\begin{array}{c}0.329 \\
(0.107)\end{array}$ & $\begin{array}{c}0.294 \\
(0.107)\end{array}$ & $\begin{array}{c}0.364 \\
(0.190)\end{array}$ \\
\hline $\begin{array}{l}\text { Adjusted } R^{2} \\
\text { Stability }\end{array}$ & $\begin{array}{l}0.015 \\
0.898\end{array}$ & 0.015 & 0.005 & $\begin{array}{l}0.027 \\
0.536\end{array}$ & 0.017 & 0.030 \\
\hline $\begin{array}{l}\text { Dividend- } \\
\text { price ratio }\end{array}$ & $\begin{array}{c}8.113 \\
(4.810)\end{array}$ & $\begin{array}{l}11.020 \\
(5.723)\end{array}$ & $\begin{array}{c}3.321 \\
(8.936)\end{array}$ & $\begin{array}{c}2.960 \\
(5.083)\end{array}$ & $\begin{array}{l}19.590 \\
(7.320)\end{array}$ & $\begin{array}{c}-4.872 \\
(10.523)\end{array}$ \\
\hline $\begin{array}{l}\text { Adjusted } \mathbf{R}^{2} \\
\text { Significance } \\
\text { Stability }\end{array}$ & $\begin{array}{l}0.026 \\
0.093 \\
0.940\end{array}$ & $\begin{array}{l}0.038 \\
0.056\end{array}$ & $\begin{array}{l}0.018 \\
0.711\end{array}$ & $\begin{array}{l}0.025 \\
0.561 \\
0.019\end{array}$ & $\begin{array}{l}0.073 \\
0.008\end{array}$ & $\begin{array}{l}0.021 \\
0.644\end{array}$ \\
\hline Short rate & $\begin{array}{l}-2.703 \\
(1.254)\end{array}$ & $\begin{array}{l}-2.148 \\
(2.237)\end{array}$ & $\begin{array}{l}-4.166 \\
(1.781)\end{array}$ & $\begin{array}{l}-3.897 \\
(1.494)\end{array}$ & $\begin{array}{l}-4.292 \\
(1.682)\end{array}$ & $\begin{array}{l}-1.718 \\
(3.982)\end{array}$ \\
\hline $\begin{array}{l}\text { Adjusted } \mathbf{R}^{2} \\
\text { Significance } \\
\text { Stability }\end{array}$ & $\begin{array}{l}0.028 \\
0.032 \\
0.601\end{array}$ & $\begin{array}{l}0.016 \\
0.339\end{array}$ & $\begin{array}{l}0.039 \\
0.021\end{array}$ & $\begin{array}{l}0.056 \\
0.010 \\
0.886\end{array}$ & $\begin{array}{l}0.065 \\
0.012\end{array}$ & $\begin{array}{l}0.021 \\
0.667\end{array}$ \\
\hline $\begin{array}{l}\text { Dividend- } \\
\text { price ratio } \\
\text { Short rate }\end{array}$ & $\begin{array}{l}23.589 \\
(6.429) \\
-7.421 \\
(1.804)\end{array}$ & $\begin{array}{l}23.169 \\
(7.368) \\
-7.232 \\
(2.824)\end{array}$ & $\begin{array}{c}28.333 \\
(12.523) \\
-9.909 \\
(2.953)\end{array}$ & $\begin{array}{l}9.282 \\
(5.190) \\
-5.208 \\
(1.562)\end{array}$ & $\begin{array}{l}20.691 \\
(7.392) \\
-4.568 \\
(1.650)\end{array}$ & $\begin{array}{c}-2.920 \\
(21.158) \\
-0.784 \\
(8.100)\end{array}$ \\
\hline $\begin{array}{l}\text { Adjusted } R^{2} \\
\text { Significance } \\
\text { Stability }\end{array}$ & $\begin{array}{l}0.100 \\
0.000 \\
0.423\end{array}$ & $\begin{array}{l}0.096 \\
0.007\end{array}$ & $\begin{array}{l}0.109 \\
0.004\end{array}$ & $\begin{array}{l}0.070 \\
0.004 \\
0.167\end{array}$ & $\begin{array}{l}0.129 \\
0.001\end{array}$ & $\begin{array}{l}0.011 \\
0.898\end{array}$ \\
\hline
\end{tabular}

[CONTINUED] 
TABLE 2 (CONTINUED)

U.S. STOCK RETURNS

JAPANESE STOCK RETURNS

\begin{tabular}{lcccccc}
\hline & 71.89 & $71-80$ & $81-89$ & $71-89$ & $71-80$ & $81-89$ \\
\hline & & & & & & \\
Change in & -10.789 & -17.799 & -1.875 & -8.947 & -11.703 & 5.091 \\
short rate & $(4.539)$ & $(5.263)$ & $(7.113)$ & $(4.658)$ & $(4.975)$ & $(12.282)$ \\
& & & & & & \\
Adjusted R & 0.055 & 0.131 & -0.004 & 0.032 & 0.032 & 0.021 \\
$\begin{array}{l}\text { Significance } \\
\text { Stability }\end{array}$ & 0.018 & 0.001 & 0.793 & 0.476 & 0.020 & 0.679 \\
& 0.352 & & & &
\end{tabular}

\begin{tabular}{|c|c|c|c|c|c|c|}
\hline $\begin{array}{l}\text { Long-short } \\
\text { spread }\end{array}$ & $\begin{array}{c}6.916 \\
(2.278)\end{array}$ & $\begin{array}{c}8.035 \\
(3.351)\end{array}$ & $\begin{array}{c}6.869 \\
(2.980)\end{array}$ & $\begin{array}{c}3.933 \\
(1.912)\end{array}$ & $\begin{array}{c}4.718 \\
(1.959)\end{array}$ & $\begin{array}{r}-12.982 \\
(9.431)\end{array}$ \\
\hline $\begin{array}{l}\text { Adjusted } R^{2} \\
\text { Significance } \\
\text { Stability }\end{array}$ & $\begin{array}{l}0.053 \\
0.003 \\
0.888\end{array}$ & $\begin{array}{l}0.056 \\
0.018\end{array}$ & $\begin{array}{l}0.035 \\
0.023\end{array}$ & $\begin{array}{l}0.043 \\
0.041 \\
0.294\end{array}$ & $\begin{array}{l}0.059 \\
0.018\end{array}$ & $\begin{array}{l}0.046 \\
0.172\end{array}$ \\
\hline
\end{tabular}

\begin{tabular}{|c|c|c|c|c|c|c|}
\hline $\begin{array}{l}\text { Dividend- } \\
\text { price ratio } \\
\text { Change in } \\
\text { short rate } \\
\text { Long-short } \\
\text { spread }\end{array}$ & $\begin{array}{c}9.257 \\
(4.486) \\
-7.347 \\
(4.562) \\
6.219 \\
(2.392)\end{array}$ & $\begin{array}{c}13.230 \\
(5.305) \\
-14.388 \\
(5.223) \\
6.362 \\
(3.227)\end{array}$ & $\begin{array}{c}5.782 \\
(8.423) \\
1.257 \\
(6.754) \\
7.473 \\
(3.160)\end{array}$ & $\begin{array}{c}4.644 \\
(5.072) \\
-6.490 \\
(4.342) \\
4.060 \\
(1.919)\end{array}$ & $\begin{array}{l}21.324 \\
(7.431) \\
-5.557 \\
(4.439) \\
5.249 \\
(1.937)\end{array}$ & $\begin{array}{c}0.258 \\
(11.297) \\
4.600 \\
(12.479) \\
-12.981 \\
(10.257)\end{array}$ \\
\hline $\begin{array}{l}\text { Adjusted } \mathrm{R}^{2} \\
\text { Significance } \\
\text { Stabilicy }\end{array}$ & $\begin{array}{l}0.089 \\
0.002 \\
0.380\end{array}$ & $\begin{array}{l}0.171 \\
0.000\end{array}$ & $\begin{array}{l}0.021 \\
0.129\end{array}$ & $\begin{array}{l}0.045 \\
0.048 \\
0.027\end{array}$ & $\begin{array}{l}0.131 \\
0.002\end{array}$ & $\begin{array}{l}0.026 \\
0.529\end{array}$ \\
\hline
\end{tabular}

Notes: The sample periods for this table are 1971:1-1989:3, 1971:1-1980:12, and 1981:1-1989:3, with 219, 120, and 99 observations respectively. All regressions include a constant and January dumm. Heteroskedasticity-consistent standard errors are reported in parencheses. "Significance" is the joint significance of all the coefficients in the regression other than on the constant and January dummy. "Stability" is the rejection significance level for the hypothesis that all coefficients in the subsample (including those on the constant and January dummy) are equal to those in the other two-thirds of the sample. Comparable results are obtained if the constant and January dumy are omitted from the stability test. 
TABLE 3

FORECASTING EXCESS STOCK RETURNS

WITH INTERNATIONAL VARIABLES

U.S. STOCK RETURNS

JAPANESE STOCK RETURNS

\begin{tabular}{|c|c|c|c|c|c|c|}
\hline & 71.89 & $71-80$ & $81-89$ & $71-89$ & $71-80$ & 81.89 \\
\hline Short rate level spe & ification & & & & & \\
\hline $\begin{array}{l}\text { U.S. } \\
\text { dividend-price ratio } \\
\text { U.S. } \\
\text { short rate } \\
\text { Japanese } \\
\text { dividend-price ratio } \\
\text { Japanese } \\
\text { short race }\end{array}$ & $\begin{array}{l}24.526 \\
(6.356) \\
-7.467 \\
(1.867) \\
-1.582 \\
(4.746) \\
-1.261 \\
(2.032)\end{array}$ & $\begin{array}{l}25.573 \\
(7.764) \\
-6.014 \\
(2.946) \\
10.909 \\
(7.626) \\
-1.170 \\
(2.122)\end{array}$ & $\begin{array}{c}26.538 \\
(16.534) \\
-10.351 \\
(3.065) \\
-1.950 \\
(28.365) \\
3.164 \\
(9.073)\end{array}$ & $\begin{array}{l}-4.443 \\
(5.137) \\
-1.128 \\
(1.549) \\
6.778 \\
(5.508) \\
-4.129 \\
(1.608)\end{array}$ & $\begin{array}{l}1.717 \\
(7.070) \\
-2.115 \\
(2.124) \\
17.758 \\
(9.555) \\
-4.101 \\
(1.679)\end{array}$ & $\begin{array}{l}-41.231 \\
(11.911) \\
-3.482 \\
(2.138) \\
79.951 \\
(26.378) \\
-2.309 \\
(7.921)\end{array}$ \\
\hline $\begin{array}{l}\text { Adjusted } R^{2} \\
\text { Significance (All) } \\
\text { Significance (U.S.) } \\
\text { Significance (Japan) } \\
\text { Stability }\end{array}$ & $\begin{array}{l}0.096 \\
0.001 \\
0.000 \\
0.691 \\
0.388\end{array}$ & $\begin{array}{l}0.092 \\
0.018 \\
0.005 \\
0.307\end{array}$ & $\begin{array}{l}0.092 \\
0.020 \\
0.005 \\
0.922\end{array}$ & $\begin{array}{l}0.074 \\
0.003 \\
0.139 \\
0.038 \\
0.001\end{array}$ & $\begin{array}{l}0.120 \\
0.001 \\
0.563 \\
0.022\end{array}$ & $\begin{array}{l}0.105 \\
0.001 \\
0.000 \\
0.001\end{array}$ \\
\hline
\end{tabular}

\section{Yield spread specification}

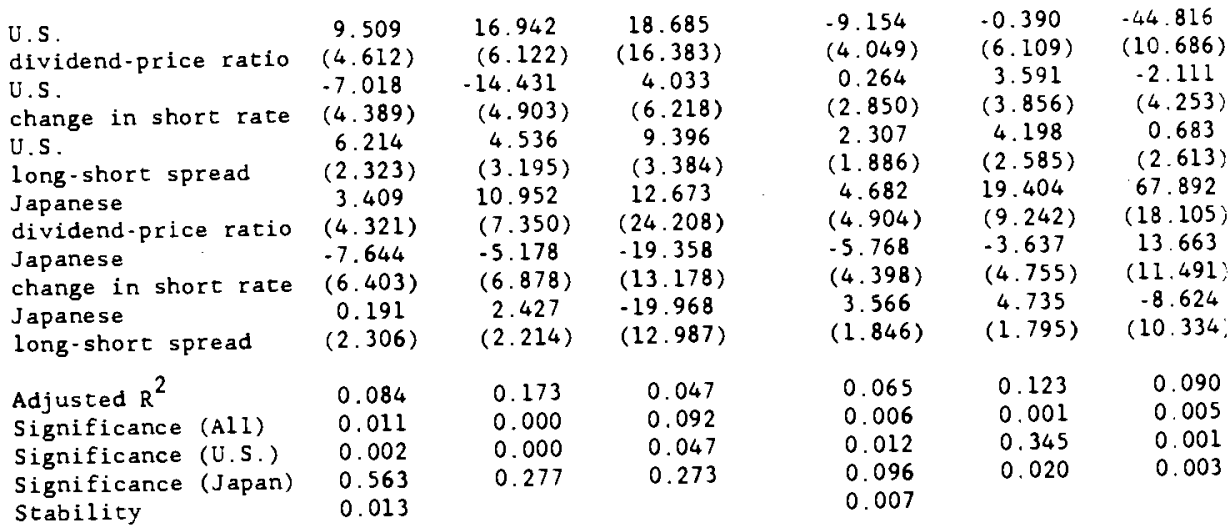

[NOTES ON NEXT PAGE] 
Notes: The sample periods for this table are 1971:1-1989:3, 1971:1-1980:12, and 1981:11989:3, with 219, 120, and 99 observations respectively. All regressions include a constant and January dummy. Heteroskedasticity-consistent standard errors are reported in parentheses. "Significance. (All)" is the jolnt signiflcance of all the coefficients in the regression other than on the constant and January dumm. "Significance (U.S.)" and "Slgnificance (Japan)" are the jolnt slgniflcance levels of the U.S. and Japanese variables, respectively. "Stabllity" is the rejection significance level for the hypothesis that all coefficients in the subsample (Including those on the constant and January dumm) are equal to those in the other two-thirds of the sample. Comparable results are obtained if the constant and January dummy are omltted from the stability test. 
AN OBSERVABLE FACTOR MODEL FOR THE EXCESS JAPANESE STOCK RETURN

JAPANESE STOCK RETURN

\begin{tabular}{lcc}
\hline & $71-80$ & $81-89$ \\
\hline & & \\
Short rate level specification & & \\
\hline U.S. & 0.253 & 0.410 \\
excess stock return & $(0.103)$ & $(0.076)$ \\
Adjusted R ${ }^{2}$ & 0.185 & 0.275 \\
Significance (A11) & 0.001 & 0.001 \\
Significance (U.S.) & 0.502 & 0.000 \\
Significance (Japan) & 0.031 & 0.001 \\
\end{tabular}

\section{Yield spread specification}

$\begin{array}{lcc}\text { U.S. } & 0.283 & 0.429 \\ \text { excess stock return } & (0.096) & (0.071) \\ & & \\ \text { Adjusted R }{ }^{2} & 0.198 & 0.286 \\ \text { Significance (Al1) } & 0.002 & 0.000 \\ \text { Significance (U.S.) } & 0.119 & 0.000 \\ \text { Significance (Japan) } & 0.042 & 0.000\end{array}$

Notes: The sample periods for this table are 1971:1-1989:3, 1971:1-1980:12, and 1981 1989:3, with 219, 120, and 99 observations respectively. All regressions include a constant, January dummy, and U.S. excess stock return, as well as the variables 1 ist: in Table 3 for the short rate level and yield spread specifications.

Heteroskedasticity-consistent standard errors are reported in parentheses. "Significance (Al1)" is the joint significance of all the coefficients in the regression other than on the constant, the U.S. excess return and the January dumny. "Significance (U.S.)" and "Significance (Japan)" are the joint significance levels o the U.S. and Japanese variables (other than the constant, U.S. excess return and January dummy) respectively. 
TABLE 5

AN UNOBSERVABLE FACTOR MODEL

OF EXCESS U.S. AND JAPANESE STOCK RETURNS

DEMEANED

DEMEANED AND DESEASONALIZED

\begin{tabular}{llll}
\hline $71-80$ & $81-89$ & $71-80$ & $81-89$ \\
\hline
\end{tabular}

Shore rate level speciflcation

$\begin{array}{lcccc}\begin{array}{l}\text { Japanese } \\ \text { beta }\end{array} & 1.594 & 1.342 & 1.681 & 1.411 \\ \begin{array}{l}\text { Mode1 restrictions } \\ (0.687)\end{array} & (0.443) & (0.819) & (0.571) \\ \mathrm{R}^{2} \text { ratio (U.S.) } & 0.079 & 0.085 & 0.040 & 0.042 \\ \mathrm{R}^{2} \text { ratio (Japan) } & 0.339 & 0.445 & 0.308 & 0.320 \\ \text { Unrestricted } & 0.889 & 0.853 & 0.882 & 0.817 \\ & 0.435 & 0.235 & 0.320 & 0.078\end{array}$

\section{Yield spread specification}

$\begin{array}{lcccc}\begin{array}{l}\text { Japanese } \\ \text { beta }\end{array} & 0.862 & -1.738 & 0.745 & -1.654 \\ \text { Model restrictions } & (0.250) & (1.127) & (0.250) & (1.081) \\ \mathrm{R}^{2} \text { ratio (U.S.) } & 0.089 & 0.151 & 0.046 & 0.185 \\ \mathrm{R}^{2} \text { ratio (Japan) } & 0.649 & 0.264 & 0.639 & 0.325 \\ \text { Unrestricted } & 0.761 & 0.692 & 0.586 & 0.895 \\ & 0.314 & 0.043 & 0.219 & -0.178\end{array}$

correlation

Notes: The sample periods for this table are 1971:1-1989:3, 1971:1-1980:12, and 1981:11989:3, with 219, 120, and 99 observations respectively. The table reports the results of estimating a single-latent-variable model, equation (6) in the text, on demeaned data, and demeaned and deseasonalized data (the residuals from a first-stage regression of returns on a constant and January dumy). The instruments used in the short rate level and yield spread specifications are listed in Table 3. "Japanese beta" is the estimated loading of the excess Japanese stock return on the single unobserved factor (the U.S. Loading is normalized to one), with an asymptotic standard error in parentheses. "Model restrictions" is the significance level for a test of the overidentifying restrictions of the single-latent-variable model. "R2 ratio" is the ratio of the variance of the restricted model forecast to the variance of the unrestricted regression forecast of the stock return. "Unrestricted correlation" is the correlation of the unrestricted regression forecasts of stock returns in the two countries. 
TABLE 6

FORECASTING EXCESS RETURNS ON SIZE PORTFOLIOS WITH INTERNATIONAL VARIABLES

U.S. RETURNS

JAPANESE RETURNS

$71-89 \quad 71.80$

$81-89$

71.89

$71-80$

$81-89$

Short rate level specification

Quintile I (smallest)

$\begin{array}{lllllll} & & & 0.159 & 0.167 & 0.209 & 0.083 \\ \text { Significance (All) } & 0.212 & 0.277 & 0.159 & 0.000 & 0.001 & 0.082 \\ \text { Significance (U.S.) } & 0.001 & 0.011 & 0.008 & 0.007 & 0.040 & 0.053 \\ \text { Significance (Japan) } & 0.738 & 0.596 & 0.023 & 0.012 & 0.040 & 0.425 \\ \text { Stability } & 0.024 & & & 0.138 & & .\end{array}$

Quintile 3 (middle)

\begin{tabular}{|c|c|c|c|c|c|c|}
\hline Adjusted $R^{2}$ & 0.150 & 0.187 & 0.109 & 0.157 & 0.173 & 0.127 \\
\hline Significance (All) & 0.000 & 0.006 & 0.018 & 0.000 & 0.005 & 0.020 \\
\hline Significance (U.S.) & 0.000 & 0.001 & 0.004 & 0.012 & 0.223 & 0.005 \\
\hline $\begin{array}{l}\text { S1gnificance (Japan) } \\
\text { Stability }\end{array}$ & $\begin{array}{l}0.948 \\
0.194\end{array}$ & 0.324 & 0.728 & $\begin{array}{l}0.150 \\
0.280\end{array}$ & 0.195 & 0.083 \\
\hline
\end{tabular}

Quintile 5 (largest)

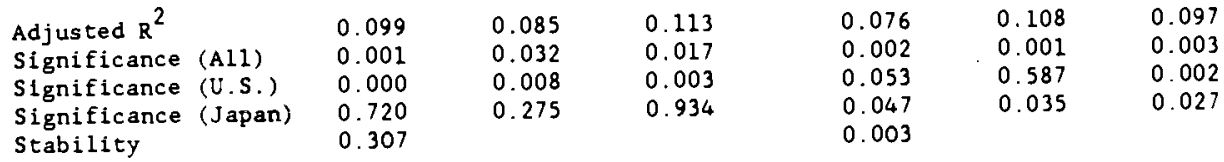

[CONTINUED] 
TABLE 6 (CONTINUED)

U.S. RETURNS

JAPANESE RETURNS

\begin{tabular}{llllll}
\hline 71.89 & 71.80 & 81.89 & 71.89 & $71-80$ & 81.89 \\
\hline
\end{tabular}

\section{Yield soread specification}

Quintile 1 (smallest)

\begin{tabular}{|c|c|c|c|c|c|c|}
\hline Adjusted $\mathbf{R}^{2}$ & 0.192 & 0.289 & 0.117 & 0.162 & 0.210 & 0.083 \\
\hline Significance (A11) & 0.006 & 0.002 & 0.166 & 0.000 & 0.003 & 0.067 \\
\hline Significance (U.S.) & 0.001 & 0.000 & 0.102 & 0.000 & 0.023 & 0.072 \\
\hline $\begin{array}{l}\text { Significance (Japan) } \\
\text { Stability }\end{array}$ & $\begin{array}{l}0.112 \\
0.002\end{array}$ & 0.537 & 0.060 & 0.122 & 0.098 & 0.314 \\
\hline
\end{tabular}

Quintile 3 (middle)

$\begin{array}{lllllll}\text { Adjusted } R^{2} & 0.127 & 0.223 & 0.073 & 0.155 & 0.174 & 0.130 \\ \text { Significance (A11) } & 0.007 & 0.000 & 0.154 & 0.001 & 0.009 & 0.006 \\ \text { Significance (U.S.) } & 0.001 & 0.000 & 0.053 & 0.000 & 0.119 & 0.004 \\ \text { Significance (Japan) } & 0.415 & 0.313 & 0.142 & 0.471 & 0.298 & 0.103 \\ \text { Stabilicy } & 0.001 & & & 0.322 & & \end{array}$

Quintile 5 (largest)

Adjusted $\mathbf{R}^{2}$

Significance (A11) 0.018

$0.147 \quad 0.080$

$0.002 \quad 0.039$

0.064

0.111

0.082

Significance (U.S.)

0.000

0.018

0.001

0.015

Significance (Japan)

0.002

0.287

0.192

0.005

0.332

0.010

Stability

0.011

0.240

0.036

0.092

Notes: The sample periods for this table are $1971: 1 \cdot 1989: 3,1971: 1-1980: 12$, and $1981: 1$. 1989:3, with 219, 120 , and 99 observations respectively. Al1 regressions include a constant and January dumny. The short rate level specification also includes U.S. and Japanese dividend-price ratios and short-term interest rates, while the yield spread specification also includes U.S. and Japanese dividend-price ratios, long-short yield spreads, and changes in short-term interest rates. "Significance (Al1)" is the joint significance of all the coefficients in the regression other than on the constant and January dummy. "Significance (U.S.)" and "Significance (Japan)" are the joint significance levels of the U.S. and Japanese variables, respectively. "Stability" is the rejection significance level for the hypothesis that all coefficients in the subsample (including those on the constant and January dummy) are equal to those in the other two-thirds of the sample. Comparable results are obtained if the constant and January dumy are omitted from the stability test. 
TABLE 7

AN UNOBSERVABLE FACTOR MODEL

OF U.S. AND JAPANESE SIZE PORTFOLIO RETURNS

DEMEANED DEMEANED AND DESEASONALIZED

\begin{tabular}{llll}
\hline $71-80$ & $81-89$ & $71-80$ & $81-89$ \\
\hline
\end{tabular}

Short rate level specification

$\begin{array}{lcccc}\text { Quintile } 1 \text { (smallest) } & 0.034 & 0.083 & 0.013 & 0.055 \\ \text { Quintile 3 (middle) } & 0.036 & 0.220 & 0.020 & 0.045 \\ \text { Quintile 5 (largest) } & 0.088 & 0.101 & 0.049 & 0.049\end{array}$

\section{Yield_spread specification}

$\begin{array}{lllll}\text { Quintile } 1 \text { (smallest) } & 0.033 & 0.209 & 0.030 & 0.101 \\ \text { Quintile } 3 \text { (middle) } & 0.055 & 0.373 & 0.037 & 0.157 \\ \text { Quintile } 5 \text { (largest) } & 0.082 & 0.020 & 0.041 & 0.037\end{array}$

Notes: The sample periods for this table are 1971:1-1989:3, 1971:1-1980:12, and 1981:1. 1989:3, with 219, 120, and 99 observations respectively. The table reports the results of estimating single-latent-variable models on demeaned data, and demeaned and deseasonalized data (the residuals from a first-stage regression of returns on a constant and January dumny). The instruments used in the short rate level and yield spread specifications are listed in Table 3 . The numbers given are significance levels for tests of the overidentifying restrictions of the single-latent-variable specification. 


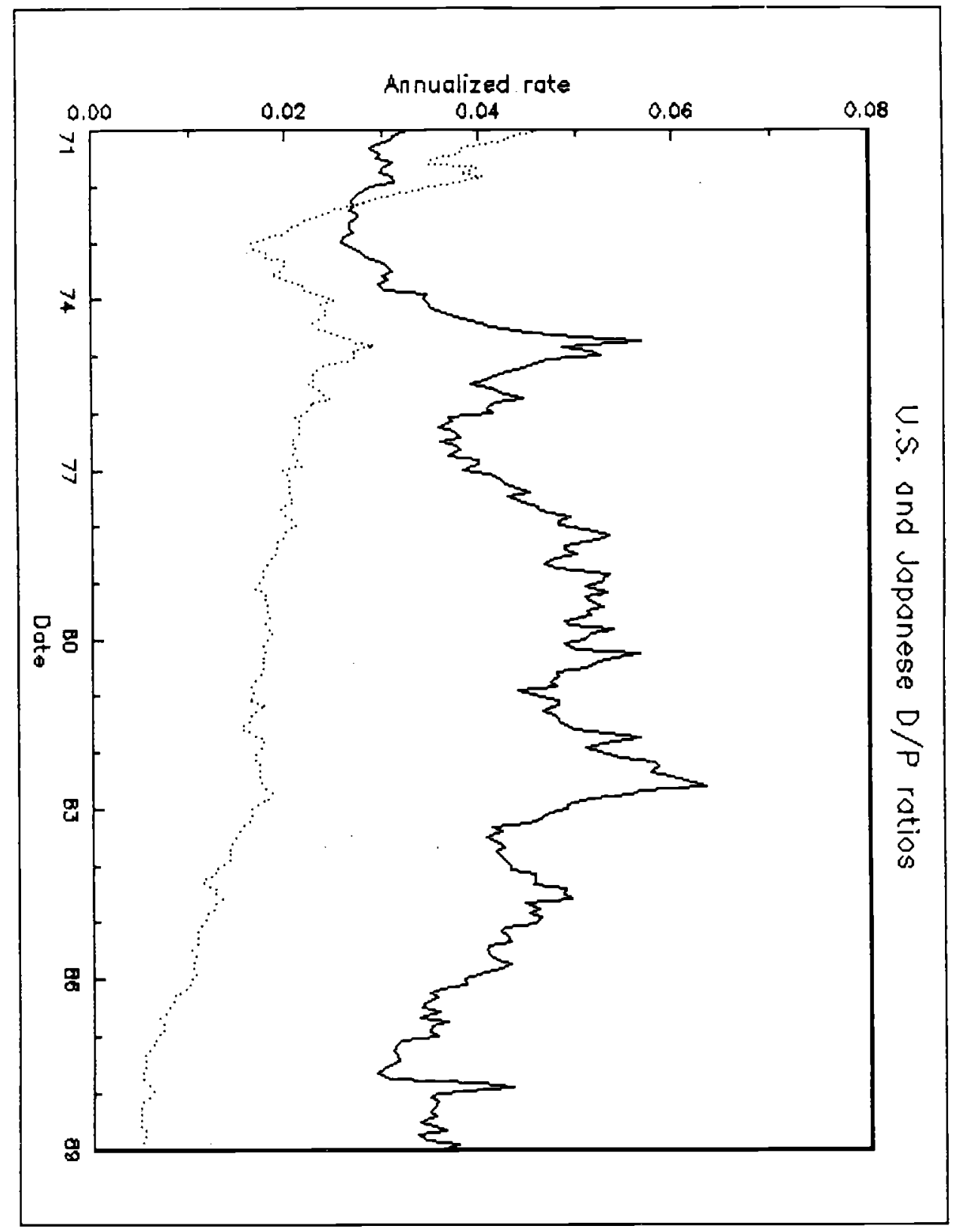

FIGURE 1

U.S. AND JAPANESE DIVIDEND-PRICE RATIOS

(Solid line is U.S., dotted line is Japan) 


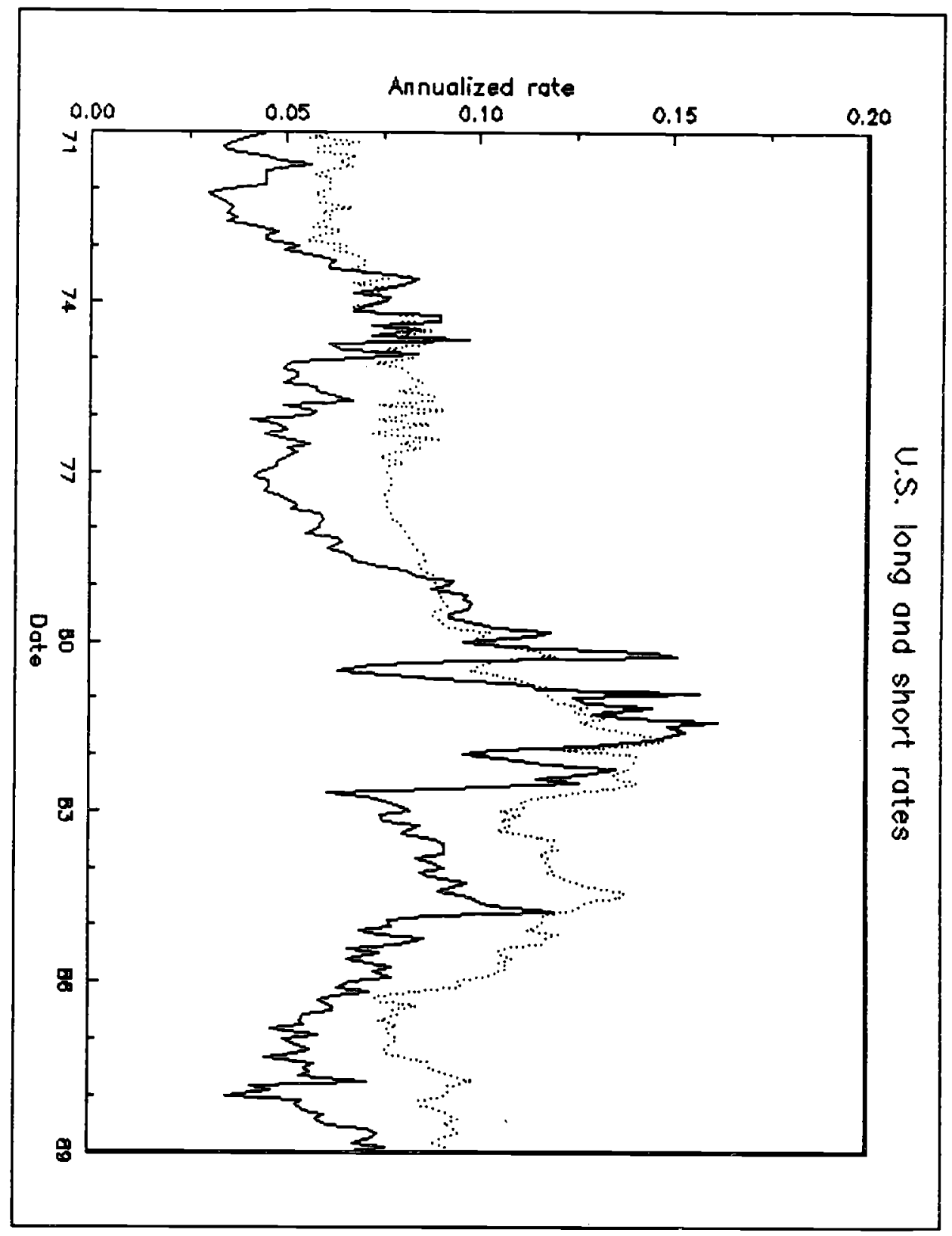

FIGURE 2

U.S. LONG- AND SHORT-TERM INTEREST RATES

(Solid line is short rate, dotted line is long rate) 


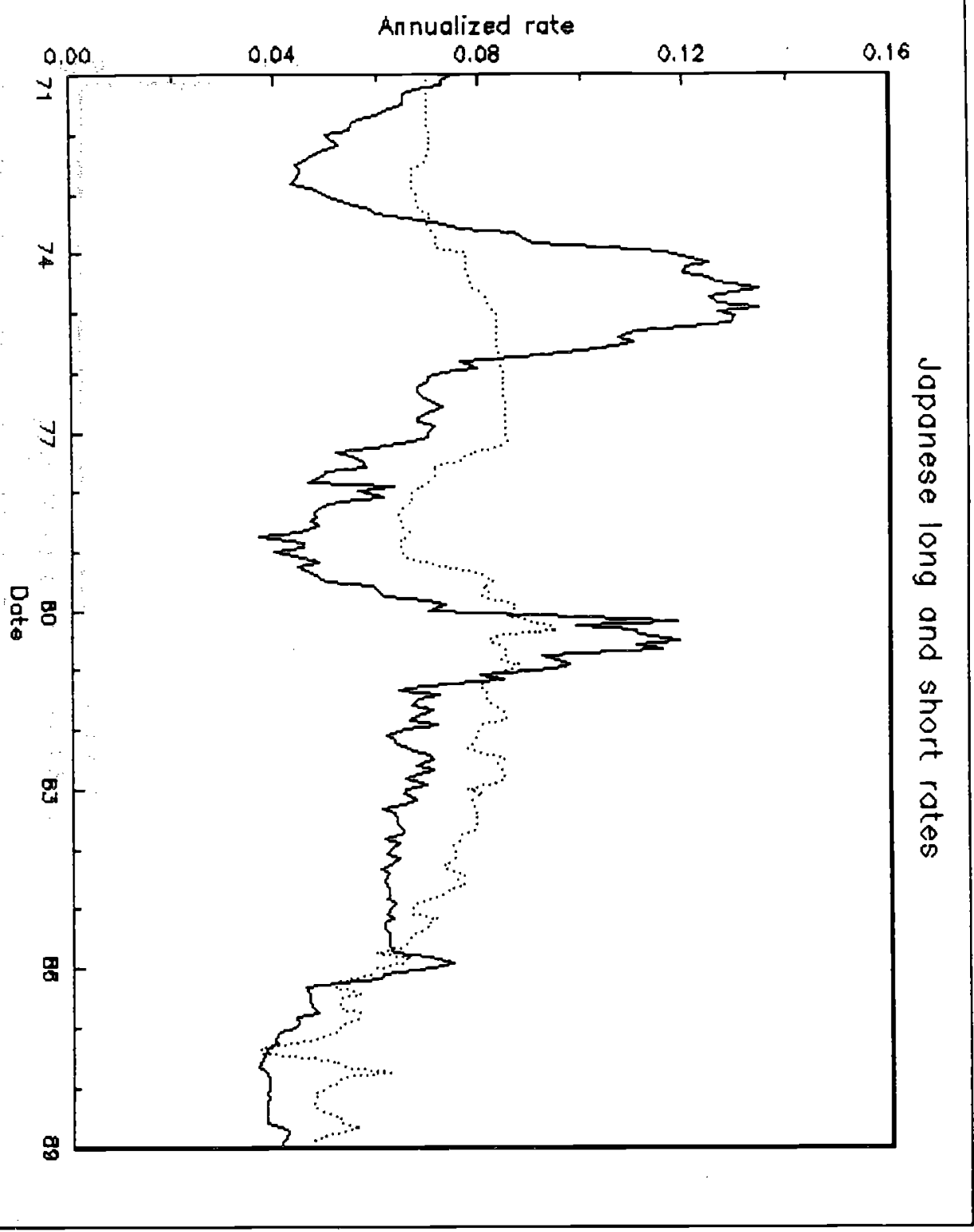

FIGURE 3

JAPANESE LONG- AND SHORT-TERM INTEREST RATES

(Solid line is short rate, dotted line is long rate) 


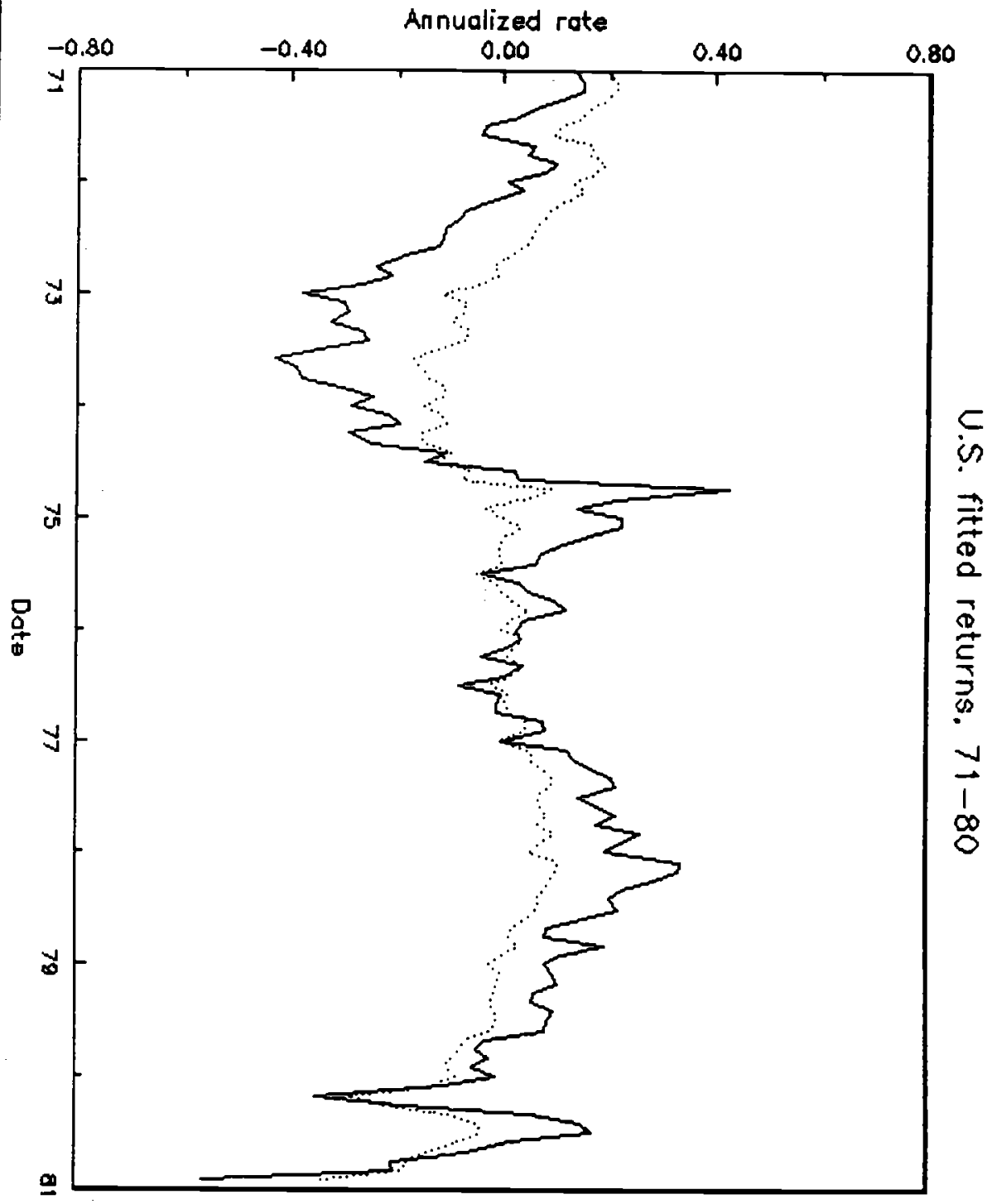

FIGURE 4a

U.S. FITTED RETURNS, $1971-1980$

(Solid line is unrestricted, dotted line is international component) 


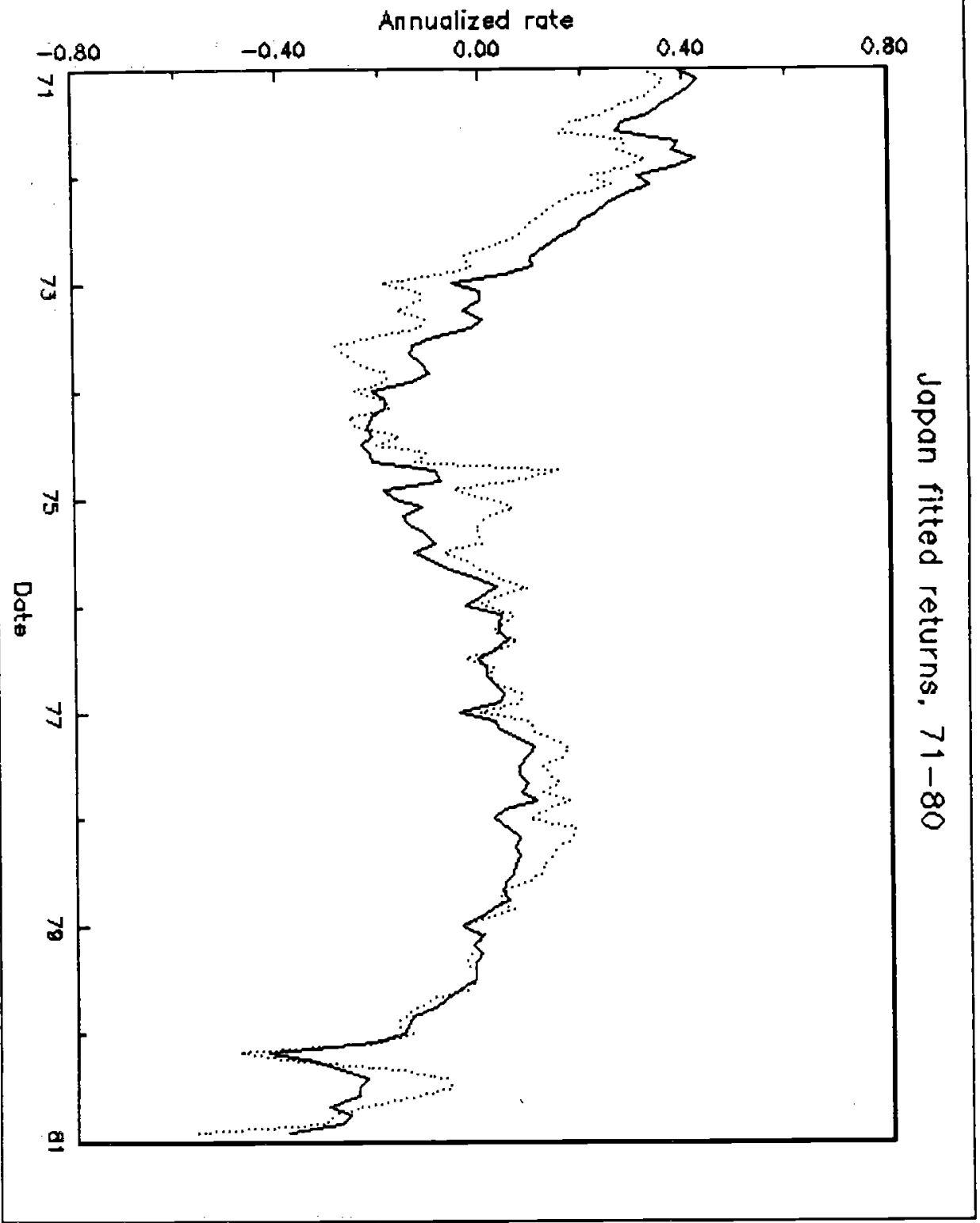

FIGURE $4 \mathrm{~b}$

JAPANESE FITTED RETURNS, 1971-1980

(Solid line is unrestricted, dotted line is international component) 


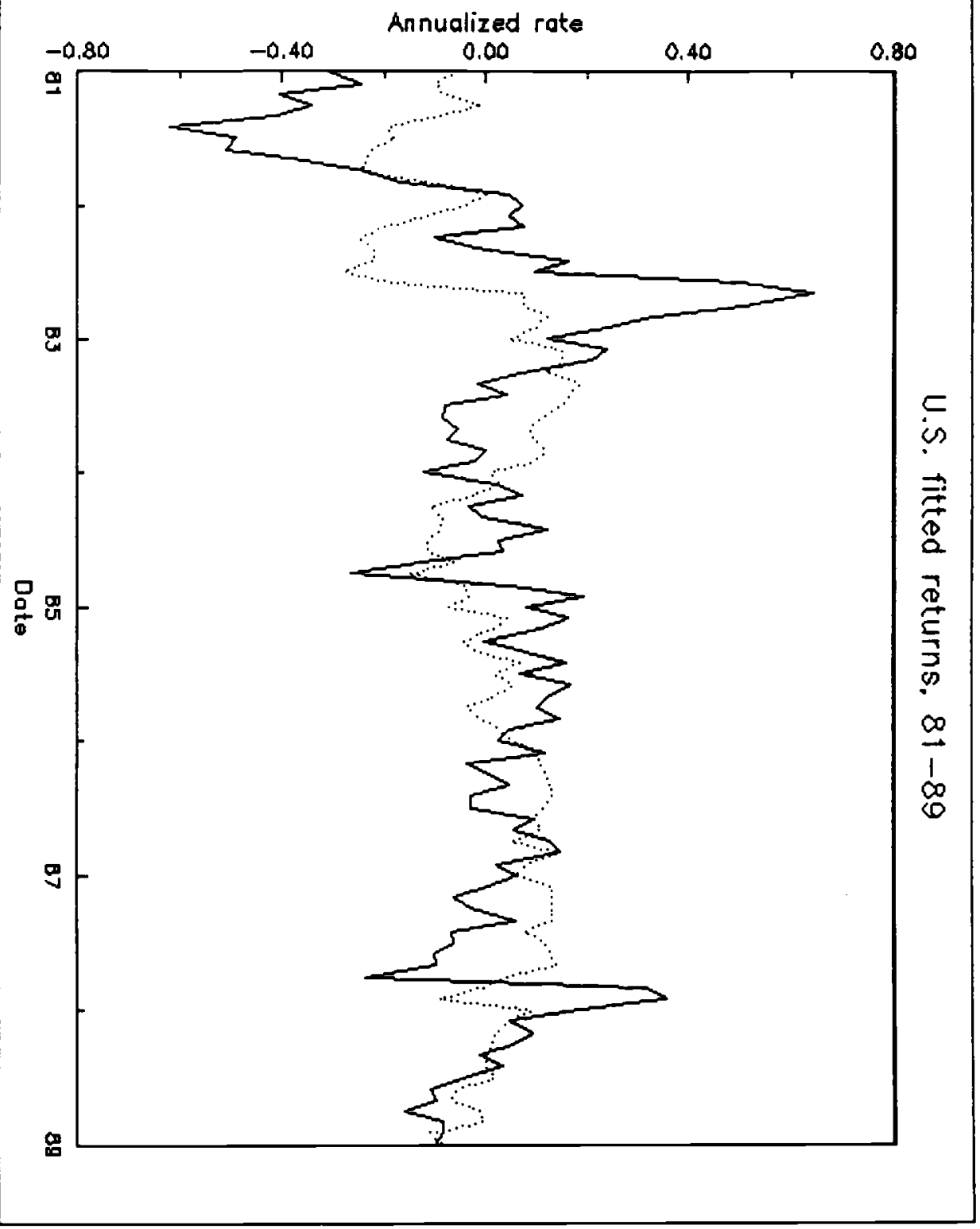

FIGURE Sa

U.S. FITTED RETURNS, 1981-1989

(Solid line is unrestricted, dotted line is international component) 


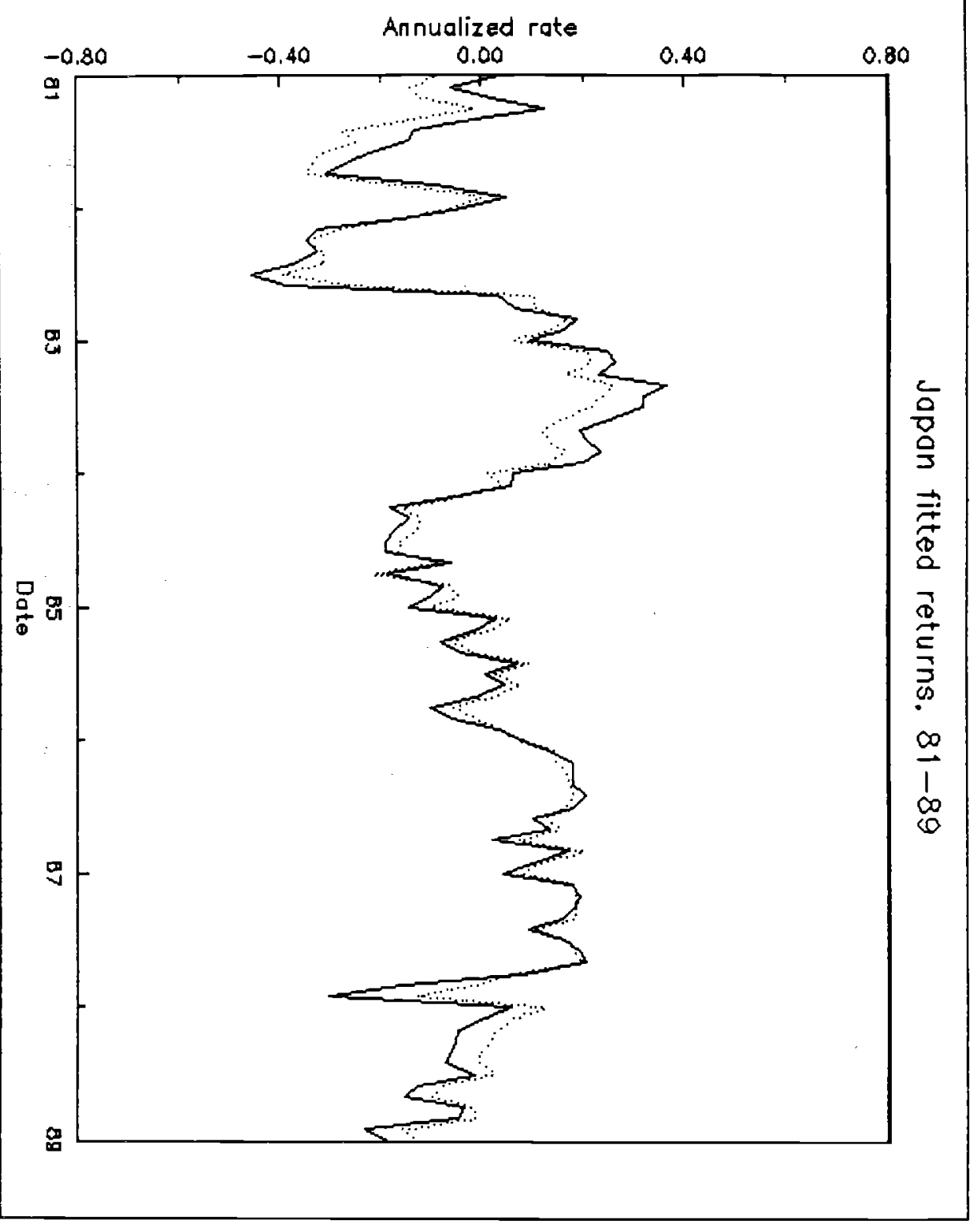

FIGURE 5b

JAPANESE FITTED RETURNS, 1981-1989

(Solid line is unrestricted, dotted line is international component) 